\title{
DWPF RISK ANALYSIS SUMMARY (U)
}

\section{C.B. Shedrow \\ Environmental Protection Department}

Publication Date: October 1990

\section{DISCLAIMER}

\begin{abstract}
This report was prepared as an account of work sponsored by an agency of the United States Government. Neither the United States Government nor any agency thereof, nor any of their employees, makes any warranty, express or implied, or assumes any legal liability or responsibility for the accuracy, completeness, or usefulness of any information, apparatus, product, or process disclosed, or represents that its use would not infringe privately owned rights. Refer. ence hercin to any specific commercial product, process, or service by trade name, trademark, manufacturer, of otherwise does not necessarily constitute or imply its endorsement, recommendation, or favoring by the United States Government or any agency thereof. The views and opinions of authors expressed herein do not necessarily state or reflect those of the United States Government or any agency thereof.
\end{abstract}

\section{Westinghouse Savannah River Company}

Savannah River Site

Aiken, South Carolina 29808 
WSRC-RP-90-1119

\title{
DWPF RISK ANALYSIS IN SUMMARY
}

\author{
by
}

\author{
C.B. Shedrow \\ Westinghouse Savannah River Company \\ Environmental Protestion Department \\ Aiken, South Carolina 29802
}

\subsection{INTRODUCTION}

Following are selected risk analysis data from Chapter 9 (Safety Analysis) of the draft DWPF SAR (DPSTSA-200-10 SUP-20, Rev 1, dtd February 1990) and draft Addendum 1 (Additional Analysis For DWPF Feed Preparation by In-Tank Processing, dtd November 1989) to the Waste Tank Farms SAR (DPSTA-200-10, SUP-18). Although these data may be revised prior to finalization of the draft SAR and the draft addendum, they are presently the best available information and were therefore used in preparing the risk analysis portion of the DWPF Environmental Analysis (DWPF EA). This information has been extracted from those draft documents and approved under separate cover so that it can be used as reference material for the DWPF EA when it is placed in the public reading rooms.

\subsection{SELECTED RISK ANALYSIS DATA}

\subsection{TANK FAILURE}

\section{Missile Penetrates Both Tanks (Section 9.2.2.4.1 in DWPF SAR)}

The frequency of a missile strike resulting from a Fujita intensity Fl tornado (73$112 \mathrm{mph}$ ) or greater is estimated in a simulation of the Pilgrim Nuclear Power Station (2) to be 3.45E-13 strikes/missile-yr- $\mathrm{ft}^{2}$. Adjusting this result to include the possibility of missile formation in high straight winds and taking into account the relative frequency of tomadoes and high straight winds at SRS gives a combined strike frequency of 9.3E-12 strikes/missile-yr-ft ${ }^{2}$. The term "missile" refers to the numerons objects present in the target area that, if they become airborme in a high wind field, can result in target penetration.

The frequency of missile strike resulting in penetration of both the inner and outer tanks is estimated based on the basic frequency developed above and on the following additional assumptions:

- 100 candidate missiles are present in the vicinity of the Organic Waste Storage Tank (OWST).

- The probability of penetrating both tanks given a strike on the outer tank is 0.1 . This probauility results from factors such as missile velocity at strike being less than the maximum possible and less than that required for penetration of both walls, and oblique angles of incidence resulting in deflection rather than penetration. 
These data lead to an estimated release frequency of:

9.3E-12 strikes/missile-yr $\mathrm{ft}^{2} \times 3040 \mathrm{ft}^{2} \times 100$ missiles $\times 1$ double penetration/10 strikes $=2.8 \mathrm{E}-07$ releases $/ \mathrm{yr}$

Because of the low frequency, the scenario is not considered credible and consequences are not analyzed.

\section{Tornado Wind Forces Result in Douhle Tank Failure (Section 9.2.2.4.2 in DWPF SAR)}

Assuming that design calculations contain a factor of safety (on applied force) of about 2.0, the approximate wind speed at failure is estimated to be $(2)^{1 / 2} \times 110=155$ $\mathrm{mph}$. The frequency of occurrence of tornado wind exceeding $155 \mathrm{mph}$ is 2 .IE-05/yr.

On a mass basis, the contents of the OWST are approximately $20 \%$ water and $80 \%$ benzene. Other organics such as phenol, biphenyl, formic acid, and methanol are also present from about $0.04 \%$ to $0.0001 \%$. Since the specific gravity of benzene is 0.88 , the volume fractions of water and benzene are $18 \%$ and $82 \%$, respectively.

If, at the time of failure, the OWST is filled to $80 \%$ of capacity (a typical maximum operating level for tanks), the maximum release will be $120,000 \mathrm{gal}$. It is assumed that $1 / 3$ of this spilled volume flows to Upper Three Runs creek via the surface drainage systern, $1 / 3$ evaporates, and $1 / 3$ is absorbed in the top soils.

Before significant leakage from the failed OWST can occur, the tomado must have moved from the immediate vicinity; it assumed that the average annual wind speed is $7 \mathrm{mph}$ (1) during evaporation.

The rate of benzene evaporation from the spill is estimated using a spread factor of $0.15 \mathrm{~m}^{2} / \mathrm{kg}\left(0.50 \mathrm{~m}^{2} / \mathrm{gal}\right.$ for benzene) and is applied based on a predominantly gravel and soil surface (3). Air temperature is assumed to be the summer average of $80^{\circ} \mathrm{F}\left(27^{\circ} \mathrm{C}\right)(1)$, and the pool temperature is assumed to be the sarne as the air. The portion of the spill assumed to evaporate is $40,000 \mathrm{gal}$, of which $82 \%$ is benzene. The resulting source strength is $5.6 \mathrm{E}+07 \mathrm{mg} / \mathrm{sec}$. At this rate, the entire 32,800 gallons of benzene would vaporize in about $30 \mathrm{~min}$.

\subsection{RISK FROM TORNADO-INDUCED FAILURE}

The risk from tomado-induced failure of the OWST result from benzene vapor inhalation, contamination of surface streams, and uptake of readioactivity via atmospheric and liquid pathways.

\section{Benzene Vapor Invalation (Section 9.2.2.5.1 in DWPF SAR)}

The Immediately Dangerous to Life and Health (IDLH) concentration for benzene is $2000 \mathrm{ppm}$ (or $6000 \mathrm{mg} / \mathrm{m}^{3}$ ). Exposure to a concentration of $60,000 \mathrm{mg} / \mathrm{m}^{3}$ for 5 minutes has been reported to result in a fatality. With a source strength of $5.6 \mathrm{E}+07 \mathrm{mg} / \mathrm{sec}$, benzene concentration exceeds the IDLH within approximately $410 \mathrm{ft}$. Potentially fatal concentrations can exist at the plume centerline within $110 \mathrm{ft}$. Calculated benzene 
concentrations at the Service Building and Administration Building air intakes are approximately $700 \mathrm{mg} / \mathrm{m}^{3}$ (or about $200 \mathrm{ppm}$ ). Median dispersion values calculated by VENTSAR are used to estimate distances and concentrations resulting from the efficient atmospheric mixing that follows the passage of a tornado (the initiating event leading to OWST' failure).

\section{Benzene Contamination of Surface Water Streams (Section 9.2.2.5.2 in DWPF SAR)}

The portion of the total benzene volume $(32,800 \mathrm{gal})$ that flows to Upper Thre Runs Creek is assumed to reach the creek over a period of $4 \mathrm{hr}$, for an average discharge rate of $8200 \mathrm{gal} / \mathrm{hr}$. The average flow rate in Upper Three Runs Creek is $265 \mathrm{ft} 3 / \mathrm{sec}$ at a point about $7 \mathrm{~km}$ downstream from S-Area drainage (4). The assumed discharge rate results in a diluted benzene concentration of $1140 \mathrm{ppm}$ in Upper Three Runs Creek. Assuming no holdup or depletion as the material moves down the creek, the discharge of Upper Three Runs into the Savannah River results in a diluted concentration of $30 \mathrm{ppm}$ at the average river flow of $10,300 \mathrm{ft}^{3} / \mathrm{sec}$ (1). Aquatic toxicity is measured by the median tolerance limit (TIM) which is the median concentration for mortality of particular aquatic species after a stated exposure time. For benzene, the TIM ranges from 10 to $100 \mathrm{ppm}$ for $96 \mathrm{hr}$ of exposure (5).

\subsection{CHEMICAL RELEASES}

\section{Cause (Section 9.4.26.1 in DWPF SAR)}

Based on operating experience in other cold feed areas the principle initiators for chemical releases are leaks, transfer errors, spills, overflows, and uncontrolled reactions. Released materials are contained in diked areas surrounding the tanks.

\section{Detection (Section 9.4.26.2 in DWPF SAR)}

Releases are detected through routine operator surveillance and by liquid level instrumentation.

\section{Frequency (Section 9.4.26.3 in DWPF SAR)}

The combined frequency of all initiators that result in a chemical release is estimated to be 1.23/vessel-yr, based on experience in F-Area and H-Area outside Facilities $(7,8)$. In F-Area the frequency is $1.52 /$ vessel-yr, and in H-Area the frequency is $0.94 / v e s s e l-y r$.

\section{Consequence (Section 9.4.26.4 in DWPF SAR)}

Leaks are the most common forms of release and their consequences are normally negligible. Overflows involve greater ouantities and their consequences bound those of leaks. Analysis of overflow data from F-Area and H-Area Outside Facilities shou $s$ the mean release is $16,400 \mathrm{lb}(7,8)$. Some volatilization of the material contained in the liked area occurs. 
The only chemicals judged to generate a sufficient quantity of hazardous fumes to create a potential exposure hazard are nitric acid and formic acid. The other substances present in cold feed storage have very low vapor pressures and therefore will not generate significant fumes.

Nitric Acid Overflow - an overflow in the outside storage area of $50 \%$ nitric acid would be totally contained in the $550-\mathrm{ft}^{2}$ diked area surrounding the tank. The resulting vapor concentration reduces to the IDLH level $\left(250 \mathrm{mg} / \mathrm{m}^{3}\right)$ within $10 \mathrm{~m}$ of the dike (source strength $=0.3 \mathrm{~g} / \mathrm{sec}$ ).

The nitric acid emission rate will increase if the spill is left uncontained within the diked area bccause of the preferential evaporation of water causing the nitric acid concentration in the solution to rise. The nitric acid emission rate increases as the nitric acid concentration in solution increases until the silution reaches the nitric acid azeotrope of 67 $w t \%$. At the azeotrope the emission rate is at a maximum and remains unchanged even if further evaporation should occur. The nitric acid emission rate at the azeotrope is 2.75 $\mathrm{g} / \mathrm{sec}$ which will exceed the IDLH concentration for a distance of $30 \mathrm{~m}$.

Eormic Acici Oyerflew - an overflow in the outside storage area of $90 \%$ formic acid would be totally contained in the $262-\mathrm{ft}^{2}$ diked area surrounding the tank. The resulting vapor concentration is above the IDLH level $\left(180 \mathrm{mg} / \mathrm{m}^{3}\right)$ for a distance of $650 \mathrm{ft}$ (source strength $=77 \mathrm{~g} / \mathrm{sec}$ ).

The emission rate for formic acid, unlike nitric acid, decreases as the pool evaporates because the concentration of the formic acid-water azeotrope is lower than the stock solution concentration of $90 \mathrm{wt} \%$. Formic acid evaporates preferentially causing a gradual decrease in the solution of formic acid concentration until formic acid concentration is reduced to the azeatropic composition of $77.5 \mathrm{wt} \%$. The formic acid emission rate is the highest immediately after the spill which results in the maximum distance to $\mathrm{DLH}$.

The above distances are based on meteorological conditions that are less favorable only $0.5 \%$ of the time.

\subsection{HAZARDOUS CHEMICAL RELEASE INSIDE VITRIFICATION BUILDING}

There are no identifiable hazards assosiated with storage of hazardous chemicals inside the Vitrification Building (Building 221-S) as long as they remain within the confines of the intended vessels and piping. The mechanisms, frequencies, and consequences of accidental chemical releases from oonfinement are analyzed in this section.

\section{Cause (Section 9.4.27.1 in DWPF SAR)}

Based on experience with other operations involving hazardous chemicals, the principle chemical release initiators are overflows, leaks, transfer errors, and uncontrolled reactions. 


\section{Detection (Section 9.4.27.2 in DWPF SAR)}

Releases are detected through routine operator surveillance and liquid level instrumentation.

\section{Frequency (Section 9.4.27.3 in DWPF SAR)}

The expected frequency for the release of hazardous vapors in an occupied area is 7.lE-0.2/yr, based on experience during F Canyon operations (6). The frequency of hazardous vapors in occupied areas of $\mathrm{F}$ canyon is 3.2E-OV/yr. Since there are at least 73 tanks in F Canyon and only 16 vessels in DWPF, the canyon frequency is reduced by the ratio $16 / 73$ to arrive at $7.1 \mathrm{E}-02 / \mathrm{yr}$.

\section{Consequence (Section 9.4.27.4 in DWPF SAR)}

Tanks containing hazardous chemicals inside Building 221-S are diked. Tanks containing volatile chemicals (except for the $50 \%$ nitric acid feed tank) have drains inside the diked areas that lead to waste holding tanks in the tunnel level of the building. Therefore, only a spill of nitric acid is likely to result in significant vapor generation. Consequences are quantitied based on overflow, since these events involve more material than leaks. The mean release from an overflow involving chemicals inside $F$ Canyon is $3570 \mathrm{lb}$.

The estimated vapor generation rate is $5.3 \mathrm{E}-03 \mathrm{~g} / \mathrm{sec}$, and the estimated airborne concentration of nitric acid is $3.9 \mathrm{ppm}$.

If the spill is allowed to evaporate, then the acid concentration in the pool increases to the azeotrope, and the vapor emission rate increases to a maximum of $4 \mathrm{E}-02 \mathrm{~g} / \mathrm{sec}$. The airborne concentrations of nitric acid reach a maxlmum of $25.5 \mathrm{ppm}$.

The above concentrations exceed the TLV of $2 \mathrm{ppm}$, but are used below the IDLH level of $100 \mathrm{ppm}$.

\subsection{BENZENE LEAK DURING TRANSFER FROM THE SALT PROCESSING CELL}

Benzene produced from the acid hydrolysis of cesium tetraphenyl borate is purified in the organic evaporator, collected in the organic evaporator condensate tank (OECT), and transferred in 350-gal batches to the organic waste storage tank (OWST). A leak in the above-ground benzene transfer line would spill benzene onto the ground.

\section{Cause (Section 9.4.28.1 in DWPF SAR)}

Failure of the overhead benzene transfer line can occur from corrosion or from damage in the course of maintenance activities. A moving crane boom striking the line could also cause failure.

Small leaks are difficult to prevent and are a common occurrence. A large leak should be noticed by the operator because of unexpectedly low flow readings. 


\section{Detection (Section 9.4.28.2 in DWPF SAR)}

Benzene transfers are monitored by a flow totalizer, FIT 9177, that indicates the total volume of benzene received.

\section{Frequency (Section 9.4 .28 .3 in DWPF SAR)}

The estimated leak frequency is $8 \mathrm{E}-06 / \mathrm{hr}$, based on the recorded occurrence of solvent leaks during operation of the F-and $\mathrm{H}$-Area Outside Facilities $(7,8)$. In F-Area, leaks occur at a rate of $2.0 \mathrm{E}-03 / \mathrm{hr}$, in $\mathrm{H}$-Area the rate is $1 . \mathrm{OE}-03 / \mathrm{hr}$. These frequencies are for all leaks, aqueous and organic. Two percent of the F-Area Outside Facility leaks and $15 \%$ of the H-Area Outside Facility leaks involve solvent.

\section{Consequence (Section 9.4.28.4 in DWPF SAR)}

The consequences of a benzene transfer leak are dominated by the toxicity of benzene rather than radionuclides which are present in very low concentrations. Tritium, the only radionuclide contributing more than $0.1 \%$ of the total body dose, is present at a concentration of $2.2 \mathrm{E}-07 \mathrm{Ci} / \mathrm{gal}$, and the total quantity released in a $350 \mathrm{gal}$ spill is $7.7 \mathrm{E}-\mathrm{O} 5$ $\mathrm{Ci}$. This is negligible compared to the normal daily releases of tritum from SRS.

A spill of $350 \mathrm{gal}$ (the maximum batch volume) is assumed to occur on an average summer day with a temperature of $80 \mathrm{~F}$. Solar energy heats the pool temperature to $10 \mathrm{C}$ higher than the air temperature (9). The wind speed at the time of the accident is assumed to be $7 \mathrm{mph}$ and inversion conditions are assumed to exist. The spill occurs on a coarse, unpaved surface, and the spread factor for gravel cited by Clewell (9) of $0.153 \mathrm{~m}^{2} / \mathrm{kg}$ is applied. Neglecting to correct for the density of benzene, the spill area is $200 \mathrm{~m}^{2}$.

The source strength is $1.08 \mathrm{~kg} / \mathrm{sec}$, and the downwind distance at which the IDLH level $\left(6000 \mathrm{mg} / \mathrm{m}^{3}\right)$ is reached is approximately $400 \mathrm{ft}$ for meteorological conditions that are less favorable oniy $0.5 \%$ of the time.

\subsection{TABLES OF DATA}

Table 1. Frequency of Exceedence of Earthquake Accelerations (Table 9.2-1 in DWPF SAR)

Table 2. Component Seismic Failure Frequencies (Table 9.2-4 in DWPF SAR)

Table 3. Radiological Risks to Offsite Maximum Individual (Adult) [Table 9.4-5 in DWPF SAR]

Table 4. Accident Summary (Table 1.1. in DPSTSA-200-10, SUP-18)

\subsection{BIBLIOGRAPHY}

1. Dukes, E.K., The Sayannah River Plant Environment. DP-142, E. I. du Pont de Nemours \& Co., Savannah River Laboratory, Aiken, SC (March 1984) 
2. Science Applications International Corporation, Simulation of Tomade Missile Hazards to the Pilerim 2 Nuclear Thermal Generating Station. Science Applications International Corporation, Sunnyvale, CA, (November 1978)

3. Clewell, H.J. III, A Simple Formula for Estimating Source Strengths from Spills of Toxic Liquids. ESL-TR-83-03. U.S. Air Force Engineering and Services Center, Tyndall AFB, FL (May 1983)

4. Department of Energy, Einal Environmental Impact Statement. Defense Waste Processing Eacility. Savannah River Plant Aiken. SC. DOE/EIS-0082,U.S. Department of Energy, Washington, DC ( February 1982)

5. Lewis, R.J., ed., Registry of Toxic Effects of Chemical Substances, National Institute for Occupational Safety and Health, Cincinnati, OH (January 1979)

6. Durant, W.S., W.C. Perkins, and T.F. Severynse, Systems Analysis - 200 Area Savannah River Plant F-Canyon Operations. Internal Report DPSTSY-200-1F, E.I. du Pont de Nemours \& Co., Savannah River Laboratory, Aiken, SC, (December 1983)

7. Durant, W.S., et al., Systems Analysis - 200 Area Savannah River Plant HCanyon Outside Facility, Internal Report DPST-200-9H, E.I. du Pont de Nemours \& Co., Aiken, SC (undated)

8. Starks, J.B., W.S. Durant and D.H. Stoddard, System Analysis - 200 Area. Sayannah River Plant. E Canyon Dutside Eacility, Internal Report DPSTSY-2009F, E.I. du Pont de Nemours \& Co., Aiken, SC (October 1985)

9. Clewell, H.J. III, A Simple Formula for Estimating Source Strengths from Spills of Toxic Liquids. Report No. ESLO-TR-83-03. U.S. Air Force Engineering and Services Center, Tyndall AFB, FL (Mr.y 1983) 
Table 1.

Frequency of Exceedence of Earthquake Accelerations

(Table $9.2-1$ in DWPF SAR)

\begin{tabular}{|c|c|}
\hline $\begin{array}{l}\text { Peak Grourd } \\
\text { acoleration (g) }\end{array}$ & $\begin{array}{c}\text { Frequency of } \\
\text { exceedance (/y par) }\end{array}$ \\
\hline $\begin{array}{l}0.03 \\
0.05 \\
0.07 \\
0.09 \\
0.11 \\
0.13 \\
0.15 \\
0.17 \\
0.19 \\
0.201 \\
0.21 \\
0.23 \\
0.25 \\
0.27 \\
0.29\end{array}$ & $\begin{array}{l}5.0 E-02 \\
1.2 E-02 . \\
5.4 E-03 \\
2.7 E-03 \\
1.5 E-03 \\
8.0 E-04 \\
5.2 E-04 \\
3.5 E-04 \\
2.4 E-04 \\
2.0 E-04 \\
1.8 E-04 \\
1.3 E-04 \\
9.0 E-05 \\
7.0 E-05 \\
5.2 E-05\end{array}$ \\
\hline
\end{tabular}

1 Design Basis Earthquake 


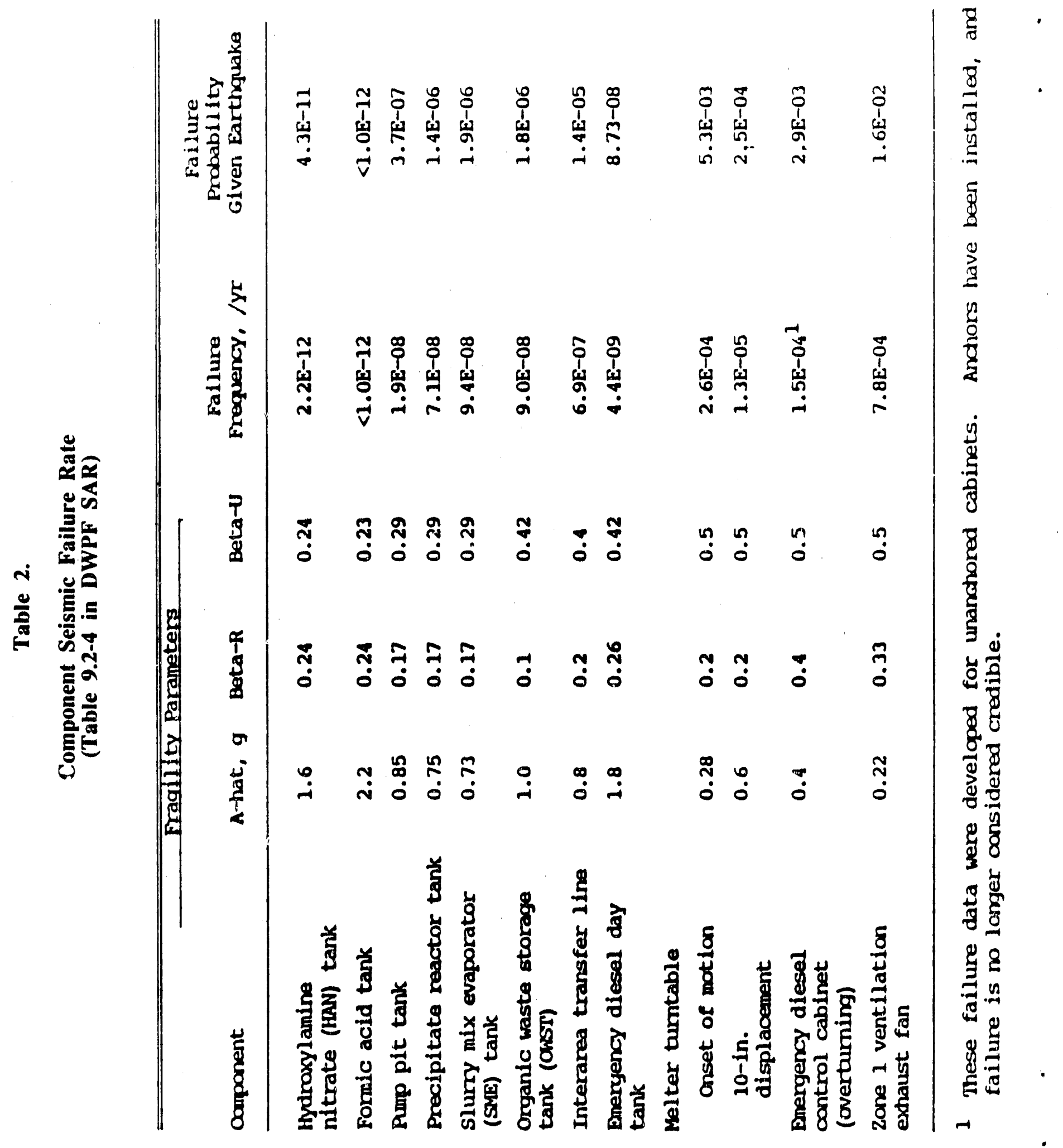




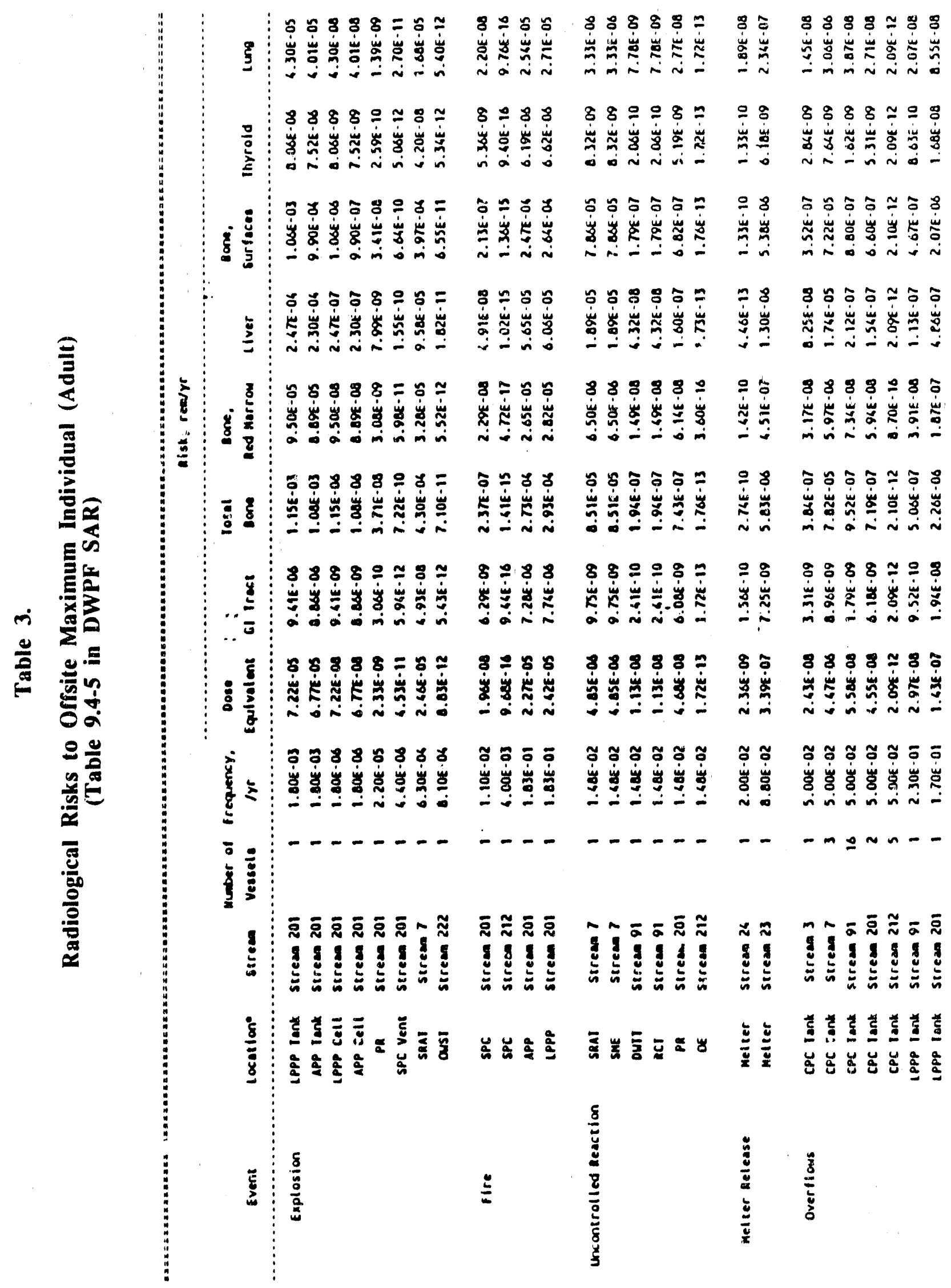




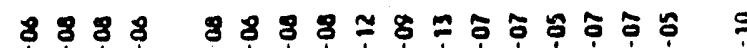

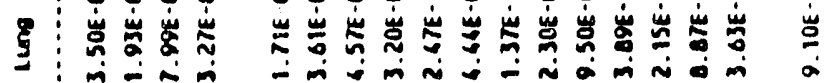

요 $=8888 \simeq 0280 \div 80 \div \div ล$

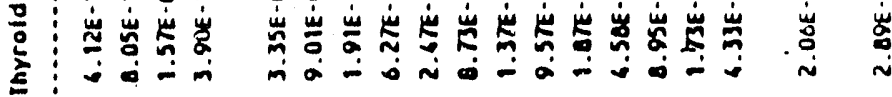

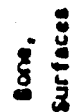

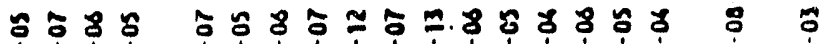

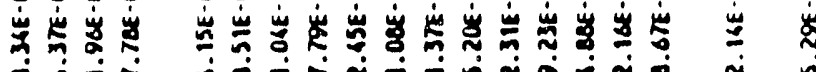

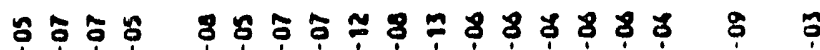

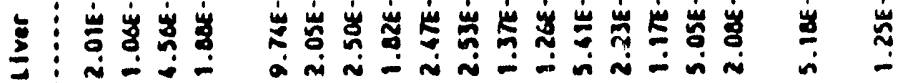

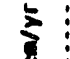

3

$83=8$

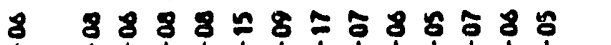

है

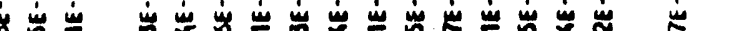

in

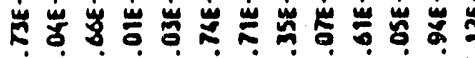

ถิํำ 8

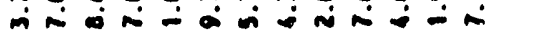

ฐ छ

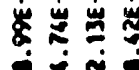

โด

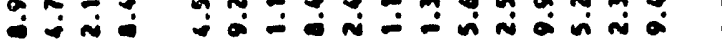

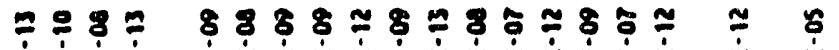

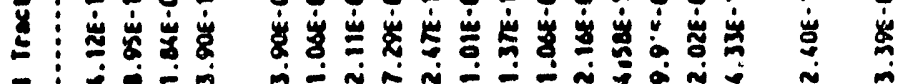

ฮ

ร: 885

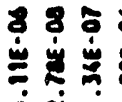

$3888 \div 8 \div 586$ ㅇำ 8

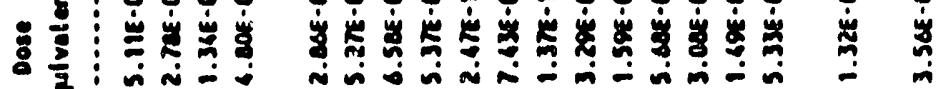

ธ $\overline{0} \overline{0}$

屁

$\dot{\mathrm{z}} \dot{\mathrm{z}} \dot{\mathrm{g}}$

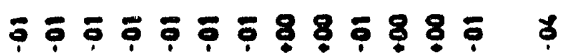

is

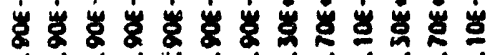

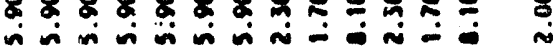

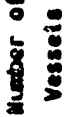

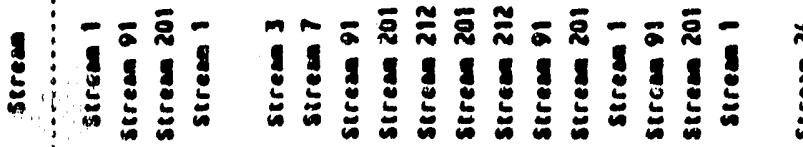

$\overline{8}$

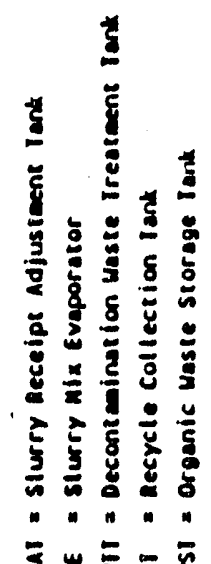

है

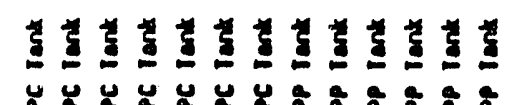

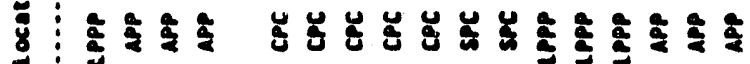

है

g 

Table 4.

Accident Summary

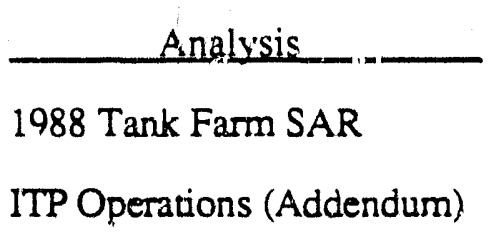

Total

\begin{tabular}{llll} 
& \multicolumn{3}{l}{ Annual Risk, man-1'em/yeara } \\
\hline $\begin{array}{l}\text { Offsite } \\
\text { Individual }\end{array}$ & $\begin{array}{l}\text { Offsite } \\
\text { Population }\end{array}$ & $\begin{array}{l}\text { H-Area } \\
\text { Personnel }\end{array}$ & $\begin{array}{l}\text { Onsitec } \\
\text { Population }\end{array}$ \\
$5.6 \mathrm{E}-5$ & $3.8 \mathrm{E}-1$ & $2.7 \mathrm{E}+0$ & $2.9 \mathrm{E}+0$ \\
$2.2 \mathrm{E}-4$ & $1.3 \mathrm{E}+0$ & $1.5 \mathrm{E}+1$ & $1.6 \mathrm{E}+1$ \\
\hline & & & \\
$3 \mathrm{E}-4$ & $2 \mathrm{E}+0$ & $2 \mathrm{E}+1$ & $2 \mathrm{E}+1$
\end{tabular}

a Based on lifetime total body dose commitments from short-term exposures and ICRP 2 dose-conve-min factors.

t. About 300 workers.

c Includes H-Area personnel. 

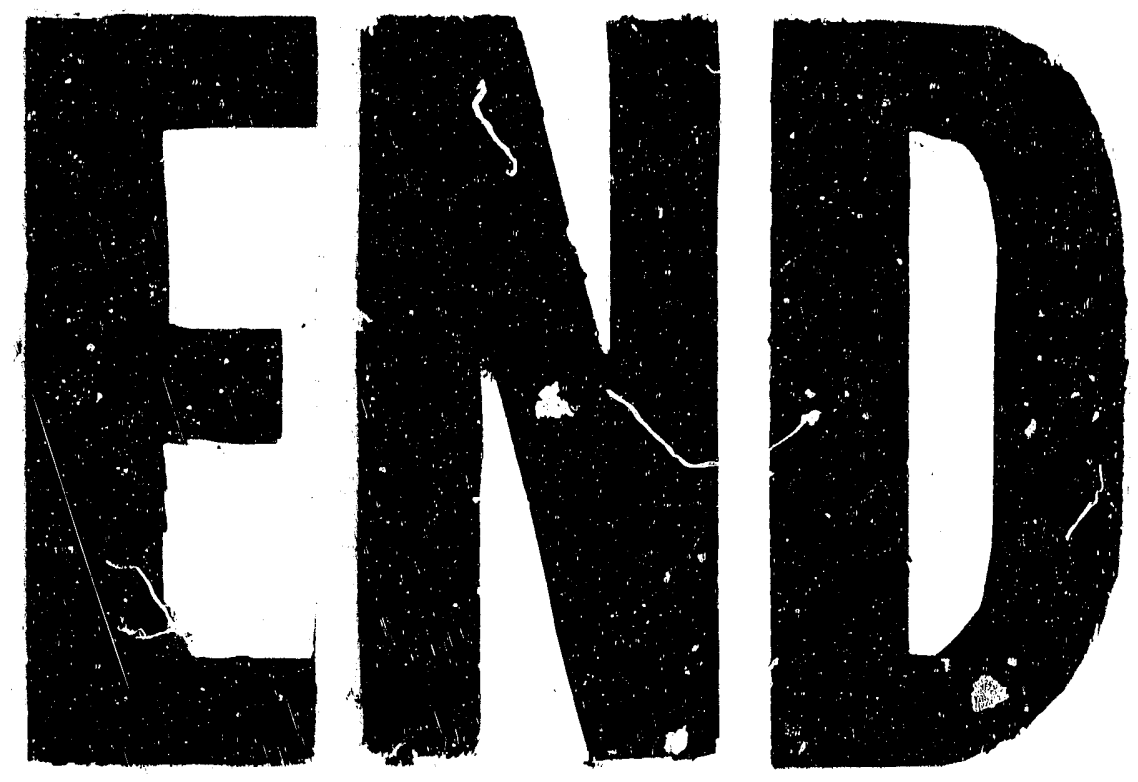

.
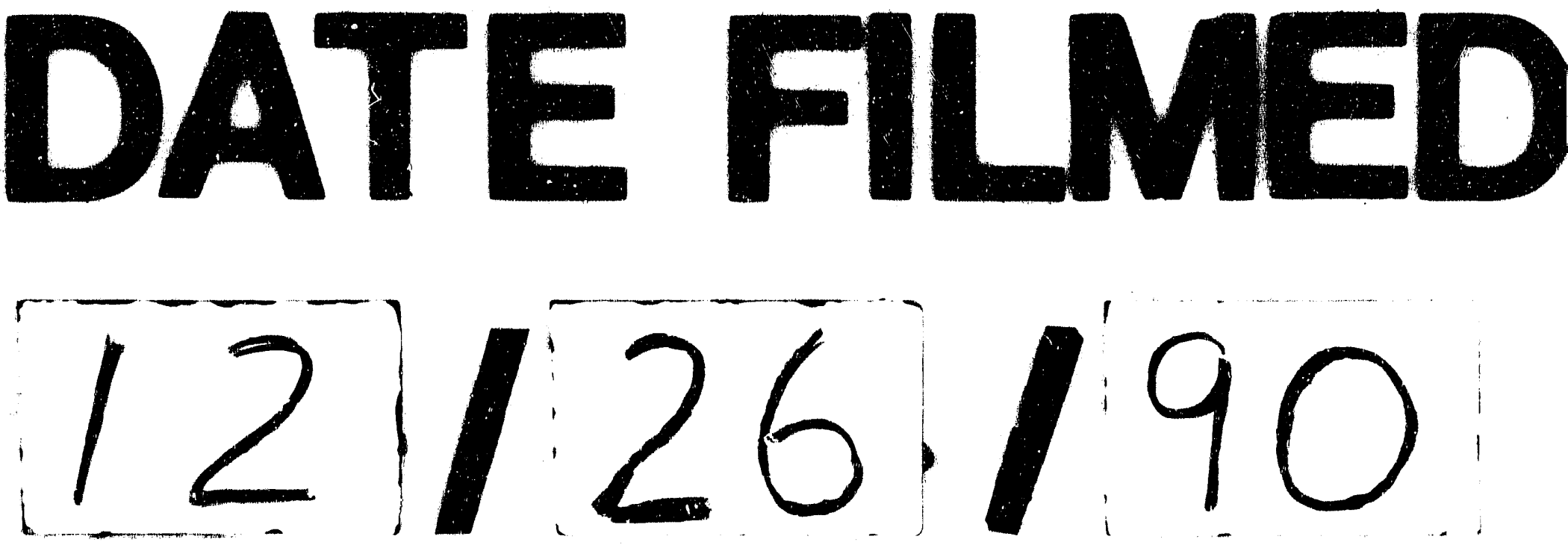


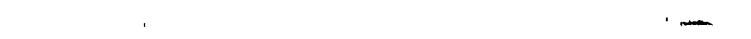

